\title{
ASSESSMENT OF EXPOSURE TO NICKEL INTAKE WITH SELECTED CEREAL GRAINS AND CEREAL-BASED PRODUCTS
}

\author{
Monika Mania', Matgorzata Rebeniak ${ }^{l}$, Oksana Orshulyak ${ }^{1}$,Jacek Postupolski ${ }^{l}$ \\ ${ }^{1}$ National Institute of Public Health - National Institute of Hygiene, \\ Department of Food Safety, 24 Chocimska str., 00-791 Warsaw, Poland
}

\begin{abstract}
Background. Cereal grains and their products are among the basic components of the diet all over the world. Their consumption varies depending on the dietary habits in each country. Apart from ingredients valuable from a health point of view, these products can also be a source of contaminants. The European Food Safety Authority (EFSA) included these foodstuffs in the group of main contributors to the dietary exposure to nickel by different groups of the population.

Objective. The aim of the studies was to determine the nickel content in cereal grains and selected cereal products commercially available in Poland and to assess the exposure of consumers to nickel intake with these foodstuffs.

Material and methods. A total of 56 samples of cereal grain and cereal products from trade were tested. Nickel content was determined after microwave mineralization of the samples by atomic absorption spectrometry with a graphite furnace atomization (GFAAS). The estimated exposure for the different groups of the population was assessed and compared with the Tolerable Daily Intake (TDI) value established by the European Food Safety Authority based on an updated risk assessment at $13 \mu \mathrm{g} / \mathrm{kg}$ body weight (b.w.) per day.

Results. The mean (MB) and 95th percentile (MB) nickel content in investigated samples of cereal grains and their products were $0.66 \mathrm{mg} / \mathrm{kg}$ and $1.93 \mathrm{mg} / \mathrm{kg}$. The mean content of $\mathrm{Ni}$ in the analyzed samples of grains was $1.16 \mathrm{mg} / \mathrm{kg}$. Obtained results in this group of products ranged from $0.10 \mathrm{mg} / \mathrm{kg}$ for rye to $4.80 \mathrm{mg} / \mathrm{kg}$ for millet. In the group of grain products, the mean (MB) concentration of nickel was $0.61 \mathrm{mg} / \mathrm{kg}$ (95th percentile (MB) $1.84 \mathrm{mg} / \mathrm{kg})$. The highest nickel level was determined in the samples of bran, groats, and flakes compared to other grain-based products. The highest content of $\mathrm{Ni}$ in the group of cereal products was found in the samples of roasted buckwheat $1.81 \mathrm{mg} / \mathrm{kg}$ and oat flakes $2.53 \mathrm{mg} / \mathrm{kg}$. Significantly lower nickel content was observed in barley groats as well as for pasta and flour.

The estimated average exposure of adults and children to nickel intake with grains and grain-based products ranged from $1.1 \%$ to $13.4 \%$ of TDI and it does not pose a health risk for consumers.

Conclusions. Based on the obtained results, it was found that the nickel content in the tested samples of cereals and their products does not pose a health risk, even though the contamination of individual samples was significant.
\end{abstract}

Key words: nickel, cereals grains, cereal-based products, intake, exposure assessment, Tolerable Daily Intake, TDI

\section{STRESZCZENIE}

Wprowadzenie. Ziarna zbóż i produkty na ich bazie są zaliczane do podstawowych składników diety na całym świecie. Ich spożycie jest zróżnicowane w zależności od nawyków żywieniowych panujących w poszczególnych krajach. Poza cennymi ze zdrowotnego punktu widzenia składnikami produkty te mogą również stanowić źródło pobrania zanieczyszczeń. Europejski Urząd ds. Bezpieczeństwa Żywności zaliczył te środki spożywcze do grupy głównych składników mogących wnosić istotny udział do pobrania niklu z dietą przez różne grupy populacji.

Cel badań. Celem badań było oznaczenie zawartości niklu w wybranych ziarnach zbóż i produktów zbożowych dostępnych w obrocie handlowym w Polsce oraz ocena narażenia konsumentów na pobranie niklu z tymi grupami środków spożywczych.

Materiał i metody. Zbadano łącznie 56 próbek zbóż oraz produktów zbożowych pochodzących z obrotu handlowego. Zawartość niklu oznaczono po mineralizacji mikrofalowej próbek metodą absorpcyjnej spektrometrii atomowej z wykorzystaniem kuwety grafitowej (GFAAS). Oszacowane narażenie w odniesieniu do różnych grup populacji porównano z wartością tolerowanego dziennego pobrania - TDI (Tolerable Daily Intake) ustaloną przez Europejski Urząd ds. Bezpieczeństwa Żywności na podstawie uaktualnionej oceny ryzyka na poziomie $13 \mu \mathrm{g} / \mathrm{kg}$ m.c./dzień.

Wyniki. Średnia zawartość niklu (MB) w badanych próbkach ziaren zbóż i ich produktów wyniosła: 0,66 mg/ $\mathrm{kg}$ (95-percentyl MB 1,93 mg/kg). Średnia zawartość Ni w analizowanych próbkach ziaren zbóż wyniosła 1,16 mg/ $\mathrm{kg}$. Uzyskane wyniki w tej grupie produktów wahały się od $0,10 \mathrm{mg} / \mathrm{kg}$ dla żyta do $4,80 \mathrm{mg} / \mathrm{kg}$ dla prosa. W grupie produktów zbożowych średnie (MB) stężenie niklu wyniosło $0,61 \mathrm{mg} / \mathrm{kg}$ (95 percentyl (MB), 1,84 mg/ kg). Najwyższą

Corresponding author: Monika Mania, National Institute of Public Health-National Institute of Hygiene, Department of Food Safety, 24 Chocimska str., 00-791 Warsaw, Poland, phone +48 225421 369, fax +48 2254 21 392, e-mail: mmania@pzh.gov.pl

(C) Copyright by the National Institute of Public Health - National Institute of Hygiene 
zawartość Ni stwierdzono w próbkach: otrąb, kasz i płatków w porównaniu z innymi produktami zbożowymi. W grupie przetworów zbożowych najwyższą zawartość Ni stwierdzono w próbce gryki prażonej 1,81 $\mathrm{mg} / \mathrm{kg}$ i płatków owsianych $2,53 \mathrm{mg} / \mathrm{kg}$. Znacząco niższą zawartość Ni otrzymano w kaszach jęczmiennych oraz w makaronie i mące.

Oszacowane średnie narażenie dorosłych i dzieci na pobranie Ni z ziarnami zbóż i produktami zbożowymi wyniosło od $1.1 \%$ do $13,4 \%$ TDI i nie stanowi ono zagrożenia dla zdrowia konsumentów.

Wnioski. Na podstawie uzyskanych wyników stwierdzono, że zawartość niklu w zbadanych próbkach zbóż i produktów zbożowych nie stanowi zagrożenia dla zdrowia, pomimo iż zanieczyszczenie pojedynczych próbek było istotne.

Słowa kluczowe: nikiel, zboża, produkty zbożowe, pobranie, ocena narażenia, TDI, Tolerowane Dzienne Pobranie

\section{INTRODUCTION}

Cereals and cereal products are important components of the daily diet [5]. These products are the source of valuable minerals, vitamins mainly from group B, fiber, protein, and carbohydrates [4, 16, 34].

The average monthly consumption of cereal products and bread in Poland is high and amounts to $5.36 \mathrm{~kg}$ per person. We eat bread the most, on average $2.89 \mathrm{~kg}$ per person per month, compared to other cereal products such as flour $0.59 \mathrm{~kg}$ or pasta $0.40 \mathrm{~kg}$ [15]. These foodstuffs can be also a source of contaminants such as heavy metals (lead, cadmium, and nickel), pesticides, and herbicides $[1,3,5,31]$. The presence of nickel is connected mainly with environmental contamination or can be connected with the migration of this metal during the production process from equipment used in the food industry or during food preparation [22, 23, 24, 29, 30, 33]. This element is also a natural component of the Earth's crust easily bioaccumulated [29].

The toxicity of nickel and its compounds has been confirmed in numerous scientific studies, including the International Agency for Research on Cancer (IARC), which has classified nickel compounds in Group I as carcinogenic to humans, and metallic nickel and nickel alloys in Group 2B as potentially carcinogenic to humans. Intake of $\mathrm{Ni}$ with a diet is associated rather with non-carcinogenic effects [22, 23, 24]. However, the mechanism of the toxic effect of nickel on the human body still requires understanding.

In 2015, European Food Safety Authority (EFSA) based on risk assessment and available data published scientific opinion on the risk to public health related to the presence of nickel in food and drinking water. EFSA indicated that grain and grain-based products are the main contributors to the dietary exposure to nickel for the general population, same as nonalcoholic beverages (except milk-based beverages), sugar and confectionery, legumes, nuts and oilseeds, and vegetables and vegetable products (including fungi), milk and dairy products [28, 29]. Based on the risk assessment a tolerable daily intake (TDI) of 2.8 $\mu \mathrm{g} / \mathrm{kg}$ b.w. was established.

In its recent opinion from 2020 CONTAM Panel of EFSA established a tolerable daily intake (TDI) at 13 $\mu \mathrm{g} \mathrm{Ni} / \mathrm{kg}$ body weight (b.w.) per day which is 4.6 times higher than in the previous risk assessment [30].

The newly established TDI value was influenced, inter alia, by an updated version of the guidance on the use of the reference dose method (BMD) in the risk assessment [10]. According to newly collected occurrence data, EFSA confirmed that grains and grain-based products mainly contributing to the mean LB (lower bound) chronic dietary exposure to nickel across all age classes with contributions reaching up to $49 \%$ in infants and toddlers $\mathrm{Ni} / \mathrm{kg}$ body weight (b.w.) per day [30].

Currently, studies on the determination of nickel contents in food are conducted in the Member States to a slightly greater extent than a few years ago. This is due to the recommendation developed in 2016 by the European Commission on monitoring the level of this contamination in various groups of foodstuffs to collect more representative data covering the entire territory of the European Union, which would allow taking appropriate measures in the area of risk management in the future [6].

Research on the absorption of nickel in the human body are still scarce, which makes it impossible to reliably assess the exposure to this element in the diet. The available information in this regard indicates a large spread in absorption (1\%-30\%), depending on many factors such as chemical form and thus, the solubility of the nickel compound, which additionally increases the uncertainty of such assessments $[13,22$, 23, 24, 29, 30].

As a critical effect for the risk characterization of acute oral exposure a systematic contact dermatitis was identified by EFSA and the lowest observed adverse effect level of $4.3 \mu \mathrm{g} \mathrm{Ni} / \mathrm{kg}$ bw was selected as the reference point. The margin of exposure (MOE) approach was also applied. MOE of 30 or higher was considered as being indicative of a low health concern.

Estimated mean chronic dietary exposure was below or at the level of the TDI. Whilst the 95th percentile chronic dietary exposure was below the TDI in adolescents and in all adult age groups, but generally exceeded the TDI in toddlers and in other children, as well as in infants in some surveys and raise a health concern in these young age groups. Calculated MOE values for mean acute dietary exposure to 95 th 
percentile exposures raise health concerns in nickel allergic individuals [30].

Currently applicable legislation of the European Union does not take into account the requirements for nickel contamination of foodstuffs, apart from the requirements for food additives [7]. For the time being, such requirements apply at national level to drinking water, natural mineral, spring and table waters $[26$, 27].

Accordingly, there is a need to protect the most vulnerable groups of the population by implementing appropriate risk management measures.

\section{MATERIALS AND METHODS}

\section{Samples}

The samples were taken from the Polish market in the years 2019-2020. They consisted of 56 samples of grain and grain-based products. The profile of the grain products under analysis was: 11 samples of pasta; 13 samples of flours; 12 samples of groats; 10 samples of flakes and 5 samples of bran. In on the group of grains were: wheat, rye, barley, and millet.

Concentration of nickel was measured by using in-house fully validated and accredited method according to standard PN-EN ISO/IEC 17025:2018. The validation was performed based on the analysis of the certified reference material - SRM 1515 (Apple leaves NIST) with certified mass fraction for nickel $0.936 \mathrm{mg} / \mathrm{kg} \pm 0.094 \mathrm{mg} / \mathrm{kg}$.

The obtained validation paramteres of the method were as follows: LOD: $0.95 \mu \mathrm{g} / \mathrm{L}$; LOQ: $1.25 \mu \mathrm{g} / \mathrm{L}$; repeatability - RSDr 7\%; correctness (relative error): $3.4 \%$, recovery: $97 \%$; range: from LOQ to $25.0 \mu \mathrm{g} / \mathrm{l}$, uncertainty $24 \%$.

\section{Equipment}

VARIAN SpectrAA $880 \mathrm{Z}$ atomic absorption spectrometer equipped with graphite furnace and Zeeman background correction was used. For graphite furnace measurements, argon was used as an inert gas. Pyrolytic-coated graphite tubes (Agilent) without platform were used. The spectrometer settings were as follows: wavelength $232.0 \mathrm{~nm}$, slit width $0.2 \mathrm{~nm}$, lamp current $4.0 \mathrm{~mA}$, argon (flow) $3.0 \mathrm{l} / \mathrm{min}$

The atomic absorption signal was measured as a peak surface mode against an analytical curve. Milestone MLS 1200 (Italy) microwave closed system at the stage of sample preparation was used.

\section{Reagents}

Nitric acid(HNO3) 65\% (Merck), hydrogen peroxide $30 \%$ (Merck), palladium matrix modifier for graphite furnace ( $\mathrm{Pd}(\mathrm{NO} 3) 2 / \mathrm{HNO} 3$ (Merck) hydrochloric acid 35\%-38\% (Chempur), L (+) - ascorbic acid (Poch), deionized water, argon. The element standard solution used for calibration was prepared by diluting a stock solution of $1 \mathrm{~g} / \mathrm{L}(\mathrm{GUM})$. All reagents used were on an appropriately high degree of purity.

\section{Elements of control and verification of the method}

The accuracy of the method was verified by the analysis of certified reference material SRM-1515 (Apple leaves NIST). As part of the external validation of results, the laboratory regularly participates in proficiency tests organized by reputable suppliers such as the UK Food Science Laboratory (FAPAS) and the EU reference laboratory for metals and nitrogenous compounds (EURL-MN), Denamrk.

\section{Samples digestion}

Approximately $0.5 \mathrm{~g}$ of sample was and transferred into clean teflon vessel then $5 \mathrm{~mL}$ of concentrated $\mathrm{HNO}_{3}$ and $1 \mathrm{~mL}$ of hydrogen peroxide were added. The digestion was lead by using a microwave in the closed mineralization system. To prevent clumping the contents of the reaction vessel were thoroughly mixed. After finished of the spontaneous reaction, the reaction vessels were quickly closed. The mineralization was carried out following the guidelines of the mineralizer producer.

\section{Calibration curve}

Scope of calibration curve: from $0 \mu \mathrm{g} / \mathrm{L}$ to 25 $\mu \mathrm{g} / \mathrm{L}$. The standard curve was prepared from one calibration solution thanks to the automatic dilution of the reagents.

\section{Statistical evaluation of data}

Statistical assessment of results was performed according to the substitution method used by EFSA for the treatment of left-censored data - LC (below limits of quantification (LOQ was $0.06 \mathrm{mg} / \mathrm{kg}$ ). For results reported to be below the $\mathrm{LOQ}$, the value equal to the LOQ (upper bound - UB), zero (lower bound $\mathrm{LB}$ ), or half the LOQ (medium or middle bound - MB) were used [31].

\section{RESULTS AND DISCUSSION}

Left-censored data (below limit of quantification), represented $27 \%$ of the analytical results for all investigated samples of grain and their products. The results are presented in Table 1. The mean (MB) and 95th percentile (MB) nickel concentration in investigated samples of grain and their products were $0.66 \mathrm{mg} / \mathrm{kg}$ and $1.93 \mathrm{mg} / \mathrm{kg}$. The average concentration of the nickel in the analyzed samples of grains was $1.16 \mathrm{mg} / \mathrm{kg}$ (MB). Nickel contents for this group of products ranged from $0.10 \mathrm{mg} / \mathrm{kg}$ for rye to $4.80 \mathrm{mg} /$ $\mathrm{kg}$ for millet. Similar results were obtained in the surveys conducted by other authors $[16,21]$. 
Table 1. Nickel content in tested samples of cereal grains and grain-based products, $\mathrm{mg} / \mathrm{kg}$

\begin{tabular}{|l|c|c|c|c|}
\hline \multirow{2}{*}{ Cereal grains and grain-based products } & \multirow{2}{*}{$\begin{array}{c}\text { Number } \\
\text { of samples }\end{array}$} & \multicolumn{3}{c|}{ Nickel content } \\
\cline { 3 - 5 } & & Mean (MB) & P95 (MB) & SD (MB) \\
\hline Cereal grains (millet, rye, wheat, barley) & 5 & 1.16 & 3.91 & 2.04 \\
\hline Pasta & 11 & 0.26 & 1.04 & 0.52 \\
\hline Flour & 13 & 0.35 & 1.35 & 0.58 \\
\hline Groats & 12 & 0.63 & 1.72 & 0.67 \\
\hline Flakes & 10 & 0.93 & 1.97 & 0.66 \\
\hline Bran & 5 & 1.34 & 1.76 & 0.36 \\
\hline All grain-based products & 51 & 0.61 & 1.84 & 0.66 \\
\hline Cereal grains and grain-based products & 56 & 0.66 & 1.93 & 0.85 \\
\hline
\end{tabular}

MB - middle bound, P95 - 95th percentile, SD - standard deviation

In the group of grain products, the mean (MB) concentration of nickel was $0.61 \mathrm{mg} / \mathrm{kg}$ (95th percentile (MB) $1.84 \mathrm{mg} / \mathrm{kg}$ ). The highest nickel level was determined in the samples of bran, groats, and flakes compared to other grain-based products. In the case of bran mean, MB was $1.34 \mathrm{mg} / \mathrm{kg}$, for flakes was 0.93 $\mathrm{mg} / \mathrm{kg}$ whilst for groats $0.63 \mathrm{mg} / \mathrm{kg}$. Another survey indicates a comparable concentration of $\mathrm{Ni}$, for groats and flakes, mean was from $0.07 \mathrm{mg} / \mathrm{kg}$ to $2.68 \mathrm{mg} / \mathrm{kg}$, and from $0.25 \mathrm{mg} / \mathrm{kg}$ to $1.16 \mathrm{mg} / \mathrm{kg}$ respectively.

The highest content of $\mathrm{Ni}$ in the group of cereal products was found in the samples of roasted buckwheat $1.81 \mathrm{mg} / \mathrm{kg}$ and oat flakes $2.53 \mathrm{mg} / \mathrm{kg}$. The obtained results are comparable with the results from other EU countries, indicating higher nickel contamination of buckwheat and oat and products from these grains as compared to other products, mean were $2.0 \mathrm{mg} / \mathrm{kg}$ and $1.8 \mathrm{mg} / \mathrm{kg}$ [29]. A study conducted in the United States and Australia also confirmed higher nickel contamination of oats and its products, obtained results were in the range: $0.36 \mathrm{mg} / \mathrm{kg}-2.10 \mathrm{mg} / \mathrm{kg}$ and $0.35 \mathrm{mg} / \mathrm{kg}-0.41 \mathrm{mg} / \mathrm{kg}$, respectively [11,36].

The survey conducted in Sweden indicates lower contamination of cereal-based products than in our studies, the mean was $0.14 \mathrm{mg} / \mathrm{kg}$ [20].

Previous studies by other authors concerning cereal products indicate even higher nickel contamination of buckwheat groats, reaching up to $2.68 \mathrm{mg} / \mathrm{kg}$ and significantly lower values in the case of oatmeal - mean $1.16 \mathrm{mg} / \mathrm{kg}$ [18]. According to new EFSA occurrence data, the mean (LB-UB) concentration of nickel in grains and grain-based products was is in the range: $0.31 \mathrm{mg} / \mathrm{kg}-0.33 \mathrm{mg} / \mathrm{kg}$ (95th percentile 1.25 $\mathrm{mg} / \mathrm{kg}-1.25 \mathrm{mg} / \mathrm{kg}$ ) [30]. Average contamination of investigated samples of pasta and flour with nickel was lower than other investigated samples of grain-based products, mean MB was $0.26 \mathrm{mg} / \mathrm{kg}$ (95th percentile $1.04 \mathrm{mg} / \mathrm{kg}$ ), and $0.35 \mathrm{mg} / \mathrm{kg}$ (95th percentile 1.35 $\mathrm{mg} / \mathrm{kg}$ ) respectively. In the case of wholemeal pasta, higher levels of nickel were observed than in the case of regular pasta made from wheat flour. The obtained results for both groups were in the range: from 0.20 $\mathrm{mg} / \mathrm{kg}$ to $1.79 \mathrm{mg} / \mathrm{kg}$ and $0.03 \mathrm{mg} / \mathrm{kg}$ to $0.08 \mathrm{mg} / \mathrm{kg}$ for pasta made from wheat flour. The survey conducted in the UK indicates comparable contamination of pasta and wheat flour, mean was about $0.03 \mathrm{mg} / \mathrm{kg}$ and 0.04 $\mathrm{mg} / \mathrm{kg}$, accordingly [12]. Similar lower contents of $\mathrm{Ni}$ in pasta were observed in France, reported mean values were as follows: $0.02 \mathrm{mg} / \mathrm{kg}$ and $0.05 \mathrm{mg} / \mathrm{kg}$ $[13,19]$. Other authors reported results for pasta in a wide range, from $0.05 \mathrm{mg} / \mathrm{kg}$ to $0.12 \mathrm{mg} / \mathrm{kg}$ [2].

A similar connection as for pasta was observed in the case of whole grain flour and wheat flour. For the first group concentration of $\mathrm{Ni}$ was much higher and ranged between $0.23 \mathrm{mg} / \mathrm{kg}$ and $2.12 \mathrm{mg} / \mathrm{kg}$. In the case of wheat flour obtained results were below LOQ value whilst contamination of spelt flour was significantly higher than wheat flour and ranged from $0.14 \mathrm{mg} / \mathrm{kg}$ to $0.18 \mathrm{mg} / \mathrm{kg}$.

The survey conducted in Spain concerning contamination of wheat flour indicates slightly higher values form $0.08 \mathrm{mg} / \mathrm{kg}$ to $0.09 \mathrm{mg} / \mathrm{kg}$ [34].

To assess the dietary exposure to nickel from commercially available grain and grain products mean and high contamination levels (P95), middle bound (MB), were taken into account. The data of the Central Statistical Office [15], and data of WHO, GEMS/ Food Consumption Cluster Diets [35] on consumption of cereals were used to assess consumption. The intake of nickel from these foodstuffs was assessed and compared to the Tolerable Daily Intake (TDI) at $13 \mu \mathrm{g} / \mathrm{kg}$ body weight per day, recently established by EFSA.

Taking into account the data of WHO, GEMS/ Food Consumption Cluster Diets on the consumption of cereal grains only (excluding rice) the assessed mean (MB) intake of nickel by adults from cereal grains would be $13.4 \%$ TDI; and do not raise a health concern. 
Intake of nickel by adults and children based on average consumption of cereal products [14] (excluding bread, rice and bakery products) and taking into account the maximum absorption in the gastrointestinal tract would be $1.1 \%$ of the TDI recently determined by EFSA for adults and 3.9\% TDI for children. At the 95-percentile level of contamination, it would be 3.4\% and $11.8 \%$ of this value. Studies conducted in Sweden indicated slightly higher exposure associated with the intake of $\mathrm{Ni}$ in cereal products by adults in comparison to our results. Mean MB intake of nickel with pasta by adults and children would be low, below $0.5 \%$ TDI and $1.3 \%$ TDI, respectively which also does not pose a health threat.

Assessed exposure was much lower than exposure to Ni intake with pasta calculated by Italian and French authors for both groups of the population $[8,19]$.

\section{CONCLUSIONS}

The content of nickel in the tested samples of selected grain and grain products does not pose a health concern

The estimated exposure do not indicate excessive nickel intake with cereal grains and their products and is unlikely to be of toxicological concern.

The obtained results may contribute to legislative work allowing for proper risk management in this area.

\section{Acknowledgements}

The study was performed under the scientific projects financed by the National Institute of Public Health National Institute of Hygiene, Warsaw, Poland (BŻ1/2020(FB-1/2020)).

\section{Conflict of interest}

The authors declare no conflict of interest.

\section{REFERENCES}

1. Akinyele I.O., Shokunbi O.S.: Concentrations of Mn, $\mathrm{Fe}, \mathrm{Cu}, \mathrm{Zn}, \mathrm{Cr}, \mathrm{Cd}, \mathrm{Pb}$, Ni in selected Nigerian tubers, legumes and cereals and estimates of the adult daily intakes. Food Chem. 2015;173:702-708.

2. Babaahmadifooladi M., Jacxsens L., Van De Wiele T., Du Laing G.: Gap analysis of nickel bioaccessibility and bioavailability in different food matrices and its impact on the nickel exposure assessment. Food Research International. 2020;129, March,108866. doi: 10.1016/j. foodres.2019.108866.

3. Bawiec P., Halabis M., Marzec Z., Kot A., Solski J., Gawel K.: Evaluation of chromium, nickel, iron and manganese content in wheat, flour, bran and selected baked products, Curr. Issues Pharm. Med. Sci. 2014;27:71-75.

4. Berski W., Achremowicz B., Gambuś F., Gambuś H.: Zawartość wybranych mikroelementów i pierwiastków śladowych w płatkach owsianych. Acta Agroph. 2017; 24(1): 5-15.

5. Chen X.X., Liu Yu-M., Zhao Q-Y., Cao W-Q., Chen X-P., Zou $C h-Q$ : Health risk assessment associated with heavy metal accumulation in wheat after long-term phosphorus fertilizer application. Environ Pollut. 2020; 262:114348.

6. Commission Recommendation (EU) 2016/1111 of 6 July 2016 on the monitoring of nickel in food. OJ L 183, 8.7.2016.

7. Commission Regulation (EU) No 231/2012 of 9 March 2012 laying down specifications for food additives listed in Annexes II and III to Regulation (EC) No 1333/2008 of the European Parliament and of the Council. OJ L 83, 22.3.2012

8. Cubadda F., Iacoponi F., Ferrari F., D'Amato M., Aureli F., Raggi A., Sette S., Turrini A., Mantovani A.: Dietary exposure of the Italian population to nickel: the national Total Diet Study. Food Chem. Toxicol. 2020; https://doi.org/10.1016/j.fct.2020.111813.

9. EFSA Scientific Committee, 2017. Update: use of the benchmark dose approach in risk assessment. EFSA Journal 2017;15(1):4658.

10. Food Standards Agency. Australia New Zealand (FSANZ). 22nd Australian Total Diet Study. 2008

11. Food Standards Agency (FSA). Total diet study: metals and other elements. Report for the UK Food Standards Agency (FS102081). M. Baxter and N. Brereton. Fera report number: $15 / 06$

12. French Agency for Food, Environmental and Occupational Health \& Safety. Second French Total Diet Study (TDS 2) Report 1. Inorganic contaminants, minerals, persistent organic pollutants, mycotoxins and phytoestrogens. ANSES, 2011, 1-77.

13. González-Weller D., Gutiérrez AJ., Rubio C., Revert C., Hardisson A.: A total diet study of nickel intake in a Spanish population (Canary Islands). Int. J Food Sci. Nutr. 2012;63(8):902-912.

14. GUS. Central Office of Statistics Database, Household budget survey in 2019. Warsaw 2020.

15.Hussain S., Rengel Z., Qaswar M., Amir M., Zafar-ulHye M.: Arsenic and heavy metals (cadmium, lead, mercury and nickel) contamination in plant- based foods; in book: Plant and Human Health, Volume 2: Phytochemistry and Molecular Aspects (pp.447-490). Springer 2019.

16. Khaneghah A.M, Fakhri Y., Nematollahi A., Pirhadi M.: Potentally toxic elements (PTEs) in cereal-based foods: A systematic review and meta-analysis. Trends in Food Science \& Techlology. 2020;96:30-44.

17. Kot A., Zaręba S., Wyszogrodzka-Koma L.: Ocena zawartości chromu i niklu w wybranych produktach zbożowych. Bromat. Chem. Toksykol. 2011;XLIV,2:176181.

18.Leblanc J-Ch., Guerin T., Noël L., Calamassi-Tran G., Volatier J-L., Verger P.: Dietary exposure estimates of 18 elements from the 1st French Total Diet Study. Food Add. Contam. 2005;22(7):624-641.

19. Livsmedels Verket. National Food Agency, Sweden. Market Basket 2010 - chemical analysis, exposure 
estimation and health-related assessment of nutrients and toxic compounds in Swedish food baskets. Repport nr 7-2012.

20.Li H-B., Wang J-Y., Chen X-Q., Li Y-P., Fan J., Ren J-H., Luo X-S., Juhasz A.L., Ma L.Q.: Geogenic nickel exposure from food consumption and soil ingestion: A bioavailability based assessment. Environ. Pollut. 2020;265:114873.

21. Mania M., Rebeniak M., Postupolski J.: Food as a source of exposure to nickel. Rocz Państw Zakl Hig 2019;70(4):393-399. https://doi.org/10.32394/ rpzh.2019.0090.

22.Mania M., Rebeniak M., Postupolski J.: Exposure assessment of the population in Poland to the toxic effects of nickel from vegetable and their products. Rocz Państw Zakl Hig 2019;70(4):401-406; https://doi. org/10.32394/rpzh.2019.0095.

23. Mania M., Szynal T., Wojciechowska-Mazurek M., Rebeniak M.: Nikiel w środkach spożywczych. Przem. Spoż. 2016;70:84-88 (in Polish).

24.Marzec Z., Koch W., Marzec A., Żukiewicz-Sobczak W.: Dietary exposure to cadmium, lead and nickel among students from south-east Poland. Ann. Agric. Environ. Med. 2014;1(4):825-828.

25. Ordinance of Polish Minister of Health of 31 March 2011 on the natural mineral waters, spring waters and potable waters. Dz. U. No. 85, item 466.

26. Ordinance of Polish Minister of Health of 13 November 2015 on the quality of water intended for human consumption. Dz. U. 2015, item 1989.

27. Pereira A.M.P.T., Silva L.J.G., Simões B.D.F., Lino $C$., Pena A.: Exposure to nickel through commercial premade baby foods: Is there any risk?. J Food Compos Anal. 2020; 92: 103541.
28. Scientific opinion of the Panel on Contaminants in the Food Chain (CONTAM) on the risks to public health related to the presence of nickel in food and drinking water. EFSA Journal 2015;13(2): 4002.

29. Scientific opinion of the Panel on Contaminants in the Food Chain (CONTAM) Update of the risk assessment of nickel in food and drinking water. EFSA Journal 2020;18(11):6268.

30. Scientific Report of EFSA. Management of leftcensored data in dietary exposure assessment of chemical substances. EFSA Journal 2010;8.

31. Ścigalska B., Puła J., Łabuz B.: Zawartość pierwiastków śladowych $\mathrm{W}$ ziarnie pszenżyta uprawianego w płodozmianie i monokulturach zbożowych. Fragm. Agron. 2011; 28(3): 112-119.

32. Szynal T., Rebeniak M., Mania M.: Migration study of nickel and chromium from ceramic and glass tableware into food. Państw Zakl Hig 2016; 67(3):247-252.

33. Tejera R.L., Luis G., González-Weller D., Caballero J.M., Gutiérrez A.J., Rubio C., Hardisson A.: Metals in wheat flour; comparative study and safety control. Nutr. Hosp. 2013; 28((2): 506-513.

34. The GEMS/Food Consumption Cluster Diets, WHO, 2007 The GEMS/Food Consumption Cluster Diets, WHO, 2007

35. U.S. Food and Drug Administration (FDA). Total Diet Study Elements Results Summary Statistics Market Baskets 2006 through 2013. 2014 revised April 2017

Received: 17.11 .2020

Accepted: 04.12.2020 